\title{
A Neurosyphilis Case Presenting with Dementia
}

Süleyman Özselek', Murat Erdem², Özcan Uzun ${ }^{3}$, A. Turan Ilıca ${ }^{4}$, Aytekin Özşahin ${ }^{5}$

${ }^{\prime}$ Assist. Dr., ${ }^{2}$ Assist. Prof. Dr., ${ }^{3}$ Assoc. Prof. Dr., ${ }^{5}$ Prof. Dr., GATA Department of Psychiatry, Ankara - Turkey ${ }^{4}$ Assist. Prof. Dr., GATA Department of Radiology, Ankara - Turkey

\begin{abstract}
A neurosyphilis case presenting with dementia

Neurosyphilis is an infection of central nervous system caused by Treponema pallidum and may present with neuropsychiatric symptoms. Neurosyphilis can mimic virtually any psychiatric disorder, including depression, mania, psychosis, personality changes, delirium and dementia. Neurosyphilis is a mysterious disease because it imitates psychiatric diseases leading difficulties in differential diagnosis. In addition, antibiotics may change its natural course, and therefore, its clinical manifestations. Mild or various forms of neurosyphillis may present, instead of the conventional form. In this paper, a case who could not have been detected at primary or secondary stages and presented with neuropsychological symptoms (tertiary neurosyphilis) was discussed.

Key words: Neurosyphilis, psychiatric symptoms, dementia
\end{abstract}

\section{ÖZET}

Demans tablosuyla gelen nörosifiliz olgusu

Nörosifiliz, Treponema pallidum'un neden olduğu, merkezi sinir sistemi tutulumu sonucu ortaya çıkan, nöropsikiyatrik bulgularla seyreden bir hastalıktır. Depresyon, mani, psikoz, kişilik değişiklikleri, deliryum ve demans başta olmak üzere hemen hemen tüm psikiyatrik bozuklukları taklit edebilir. Nörosifilizin birçok psikiyatrik hastalığa benzer görünüm gösterebilmesi, tanı karmaşası yaratması bu hastalığı gizemli bir hale getirmektedir. Ayrıca, antibiyotik kullanımı hastalı̆ı̆n doğal gidişini değiştirerek, nörosifilizin farklı klinik görünümlerde ortaya çıkmasına neden olabilir. Klasik nörosifiliz belirtileri yerine, daha hafif veya farklı klinik tablolar ortaya çıkabilir. Bu yazıda, primer ve sekonder dönemleri saptanamamış, nöropsikolojik belirtilerle ortaya çıkan bir nörosifiliz (tersiyer nörosifiliz) olgusu sunulmuş̧tur.

Anahtar kelimeler: Nörosifiliz, psikiyatrik belirtiler, demans

\author{
Address reprint requests to: \\ Assist. Dr. Süleyman Özselek, GATA \\ Department of Psychiatry, Etlik, \\ Ankara - Turkey \\ Phone: +90-312-304-4501 \\ Fax: $+90-312-304-4507$ \\ E-mail address: \\ drsuleymangata@mynet.com \\ Date of receipt: \\ October 14, 2010 \\ Date of acceptance: \\ January 29, 2011
}

\section{INTRODUCTION}

Syphilis is a multi-systemic disease which is caused by Treponema pallidum, with a chronic course and reactivations $(1,2)$. Number of syphilis cases decreased after widespread use of penicilin and other antibiotics (3). However, its importance as a sexually-transmitted disease continues in developing countries. Prevalence of concomitant AIDS and HIV-seropositivity are also increasing rapidly $(4,5)$. In this group of patients, rapid progression to neurosyphilis stage can be seen despite early and adequate treatment.

Primary syphilis is characterized by a syphilitic ulcer at inoculation site which heals in 2-3 weeks. Secondary syphilis is seen in $25 \%$ of untreated patients weeks or months after. Skin rashes, fever, lymphadenopathy and central nervous system changes are seen. Twenty-five percent of untreated patients become tertiary syphilis. Tertiary syphilis is seen 1-30 years after the primary infection $(6,7)$. Cognitive impairment and neuropsychiatric disorders are seen in tertiary syphilis.

Prevalence of syphilis and familiarity of physicians to this old disease decreased by the antibiotic era. Moreover, antibiotic use changed the natural course of the disease and caused different clinical presentations of late stage syphilis. Instead of classical neurosyphilis, combinations of milder or different clinical presentations which only some of the clinical symptoms appear are frequently seen (8). In this paper, a neurosyphilis case (tertiary syphilis) which was presented by neuropsychological symptoms and primary and secondary stages could not be detected.

\section{CASE}

Forty-five year old male patient was admitted to our hospital due to hesitant speech, remaining stuck in a word, inconsistent and aggressive behavior and 
forgetting recent events. His family members told that he could be accessed four months ago and before that he could not be contacted for two years, when found he behaved aggressively and was treated with atypical psychosis diagnosis and risperidone $3 \mathrm{mg} /$ day but he did not get benefit and even worsened. No disease or substance abuse was described in his medical history.

In his mental examination at the time of admission; his self-hygiene was inadequate, had difficulty in pursuing his speech and stuck in certain words during speech. He had blunted affect and his gesture and mimics were decreased. He was alert but disoriented in self, place and time. Short-term memory was impaired but remote memory was partially preserved. Attention, abstract thinking, reality testing and judgment were all impaired. Associations in thinking process and its content were reduced. Psychomotor activity was slow.

In neurological examination; patient was alert, his cooperation and orientation were limited and speech was dysarthritic. Pupillae were isocoric and direct and indirect light reflexes were bilaterally positive. There was no lateralized sensory or motor deficit. No meningeal irritation sign was found. Cranial nerves were intact, deep tendon reflexes were normoactive and cerebellar tests were normal. There were widespread dyskinesias at orofacial region and all four limbs which stopped at sleep and voluntary movements but continuous otherwise. Romberg test was negative. No pathological reflexes were found. Mini mental state examination score was 13/30.

Presence of speech disorder in the medical history, impairment of short-term memory, lack of self-hygiene, presence of behavioral changes, disorientation of self, place and time, and cognitive deficits such as impairment of attention, judgment and abstract thinking suggested dementia as preliminary diagnosis. Etiological factors of dementia were evaluated. Causes of primary dementia due to progressive degeneration of central nervous system were excluded due to development of the clinical picture in a relatively short time (1-2 years). Cerebrovascular disease was also excluded due to absence of focal neurological signs and laboratory findings. In cranial MR imaging, mild hyperintensity was detected at medial temporal lobes (Figure 1), absence of a mass-occupying lesion or an infarct excluded vascular dementia, normal pressure hydrocephalus and intracranial mass lesions. There was no history of substance abuse. When systemic conditions which are known to cause dementia were examined; normal values of complete blood count, blood biochemistry and urinalysis excluded systemic causes such as hypothyroidism and chronic liver disease, absence of history of drug/toxic substance intake and absence of a clinical or laboratory finding suggesting these conditions excluded toxic-metabolic causes. Vitamin B12 and folic acid levels were normal.

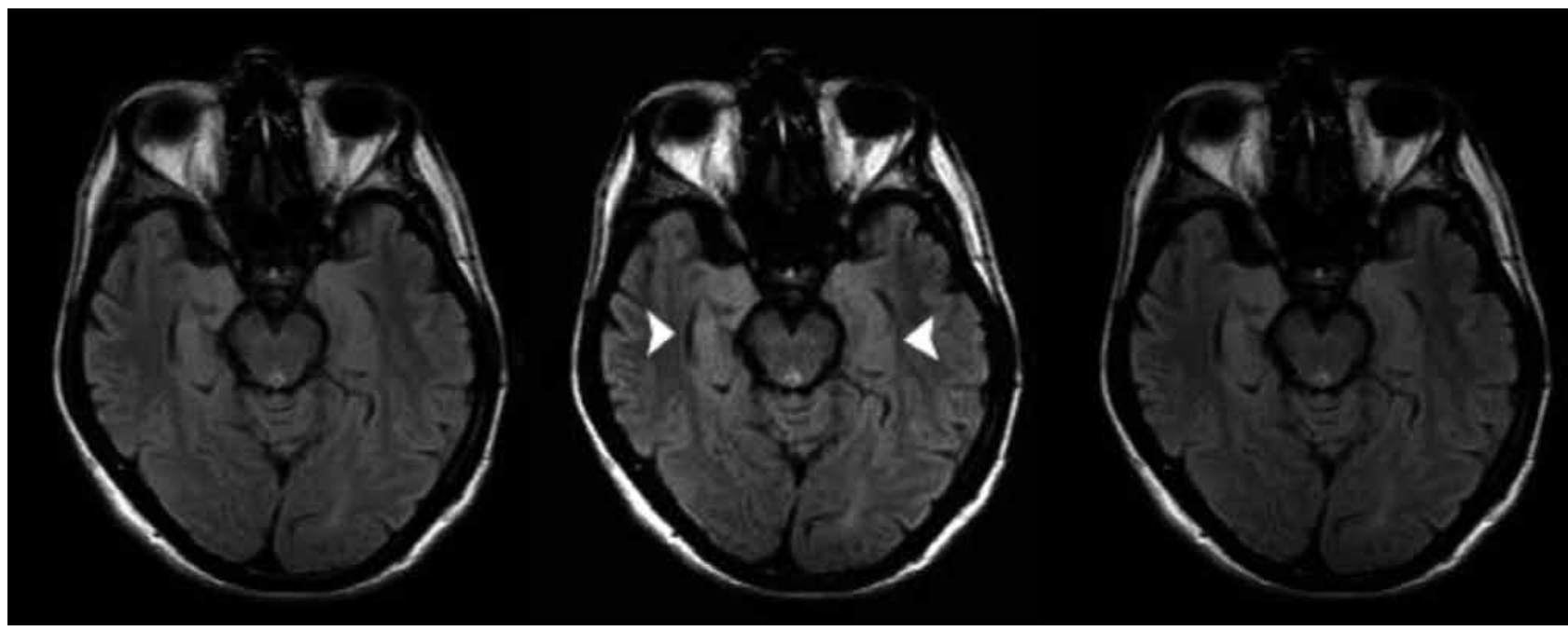

Figure 1: In fluid attention inversion recovery (FLAIR) MR imaging, mild hyperintensity can be seen in medial temporal lobes. 
HIV-related dementia was also excluded due to negative serological findings for HIV and hepatitis. No autoimmune and/or inflammatory markers were also found. Electromyography and electroencephalography were within normal limits. In somatosensorial evoked potential tests (SEP); latency and amplitudes of cortical response of bilateral median and right tibial SEP were within normal limits but cortical response latency of left tibial SEP was delayed Visual evoked potentials (VEP) and detailed neuropsychological examination could not be performed due to lack of cooperation of the patient. Serum VDRL was found positive. VDRL and TPHA (Treponema Pallidum Hemagglutination) was found positive in CSF examination. There was lymphocytic pleocytosis and positive oligoclonal band in CSF as well. No microorganism was detected in direct microscopic examination of CSF. CSF culture was negative. Mycobacterium tuberculosis complex PCR was found negative in CSF. CSF protein and glucose levels were also within normal limits. No other medical examination was performed because patient had no any other symptom and his systemic examination and electrocardiography was normal.

Clinical examination and serum and CSF serology was consistent with neurosyphilis and 24 million units/ day crystallized penicillin for 21 days and clonazepam $2 \mathrm{mg} /$ day orally for his anxiety. CSFwas notre-evaluated. His dyskinesia started to improve a week later. It is already known that patient had received antipsychotic medication and these involuntary movements were evaluated as tardive dyskinesia. No improvement was detected in his cognitive examination performed three weeks later and scored 13/30 from Mini Mental State examination. 2.4 million units benzathine penicillin/ month IM prophylaxis was planned for maintenance treatment.

\section{DISCUSSION}

Neurosyphilis is a rare clinical condition for today. It can mimic several psychiatric disorders so clinical symptoms and signs should be evaluated with great suspicion and serological test should not be neglected. No clinical or dermatological symptom or sign was found related with primary and secondary stages of syphilis in our patient's history. In HIV-negative neurosyphilis case of Acarel et al (9), no history and sign of primary and secondary stages of syphilis was reported as well. It is noteworthy that clinical picture emerged with tertiary syphilis first. This can be explained by the change in the natural course of the disease by widespread antibiotic use and not remembering the past of the patient and his family. However, although diseaserelated symptoms are generally observed in primary syphilis, only $1-2 \%$ of patients with secondary syphilis are symptomatic. Patients enter into latent/ asymptomatic phase which only serological findings are present after recovery from secondary stage. At this stage CSF is generally normal and if there are abnormal CSF findings then it is evaluated as asymptomatic neurosyphilis. Tertiary syphilis develops in more than $1 / 3$ of untreated patients $(1,2,8)$.

Our case is consistent with parenchymatous neurosyphilis. Parenchymatous neurosyphilis (dementia paralytica) which is a form of tertiary syphilis develops 10 to 20 years after the primary infection. There is a syphilitic frontotemporoparietal encephalitis basically $(10,11)$. It is characterized by general impairment of mental and physical capacity. Its insidious onset may mimic several neurological and psychiatric diseases. Neurological symptoms are tremor of lips, tongue, facial muscles and fingers, blunted affect and impairment of speech and writing. Unplanned and bizarre commitment of crime can be seen at the initial phase of the disease. This is called medico-legal stage due to these reasons. In our case, leaving home before his admission and not getting any news from him for two years can be evaluated as medico-legal stage.

Response to treatment is inadequate in parenchymatous neurosyphilis cases compared to syphilitic meningitis and meningovascular syphilis patients. This is mainly due to irreversible neuronal damage in general paresis but CNS inflammation in other forms (12). The most effective treatment of neurosyphilis is high dose IV crystallized penicillin. Response to treatment should be monitored by CSF examination. In one of the cases reported by Bozdemir et al (13), full recovery was seen after 14 days of 
treatment but no change was seen in the other case. It was reported that patient who did not recover had a more severe neurological involvement and clinical condition is irreversible after this stage. Our case was also at an advanced stage of neurosyphilis and his cognitive symptoms did not improve despite penicillin

\section{REFERENCES}

1. Bharucha NE. Infections of the nervous system: In Bradley WG, Daroff RB, Fenichel GM. Neurology in Clinical Practice. $3^{\text {th }}$ edition. London: Butterworth - Heinemann, 2000, 1334-1335.

2. Adams RD, Victor $M$, Ropper $\mathrm{AH}$ (editors). Principles of Neurology. $7^{\text {th }}$ edition, New York: Mc Graw-Hill Companies, 2000, 722-728.

3. Schmidt RP, Neurosyphilis: In Joynt RJ (editor). Clinical Neurology Vol.2 Revised edition. Philadelphia: Lippincott Williams \& Wilkins, 1992, 1-23.

4. Berger JR. Neurosyphilis in human immunodeficiency virus type 1-seropositive individuals. A prospective study. Arch Neurol 1991; 48:700-702.

5. Stamm WE, Handsfield HH, Rompalo AM. The association of genital ulcer disease and the acquisition of HIV infection in homosexual men. JAMA 1998; 260:1429.

\section{Crossef}

6. Birnbaum NR, Goldschmidt RH, Buffet WO. Resolving the common clinical dilemmas of syphilis. Am Fam Physician 1999; 59:2233-2240

7. Polsky I, Samuels SC. Neurosyphilis screening does some-times reveal an infectious cause of dementia. Geriatrics 2001; 56:60-62. treatment.

Diagnosis and treatment of syphilis before later stages hinders more severe clinical conditions which may develop. Syphilis should be considered and its laboratory markers should be examined in cognitive disorders starting especially at younger ages.

8. Rowland LP, Stefanis L. Spirochete infections: neurosyphilis: In Rowland LP (editor). Merrit's Neurology. 10 ${ }^{\text {th }}$ edition. Philadelphia: Lippincott Williams \& Wilkins, 2000, 182-185.

9. Acarel EE, Aslan IK, Karagöz N, Altın Ü, Örnek İ, Kırbaş D. HIV negatif nörosifiliz olgu sunumu. Demans Dergisi 2002; 2:27-31 (Article in Turkish).

10. Marra CM. Neurosyphilis. Central Nervous System Infectious Diseases and Theraphy. New York: Marcel Dekker Inc.,1997, 237-252.

11. Tramont EC. Treponema Pallidum (Syphilis): In Mandell GL, Bennett JE, Dolin Mandell R (editors). Douglas and Bennett's Principles and Practices of Infectious Diseases. $5^{\text {th }}$ edition. Philedelphia: Churchill Livingstone Inc., 2000, 2474-2490.

12. Saddock BJ, Saddock VA. Klinik Psikiyatri. Aydin H, Bozkurt A (Çeviri Ed.) 8. Baskı, Ankara: Güneş Kitabevi Ltd. Şti., 2007, 454 (Article in Turkish)

13. Bozdemir H, Tamam L, Özeren A, Zeren M, Sarıca Y. Neurosyphilis: Report of two patients. Annals of Medical Sciences 2000; 9:27-30. 